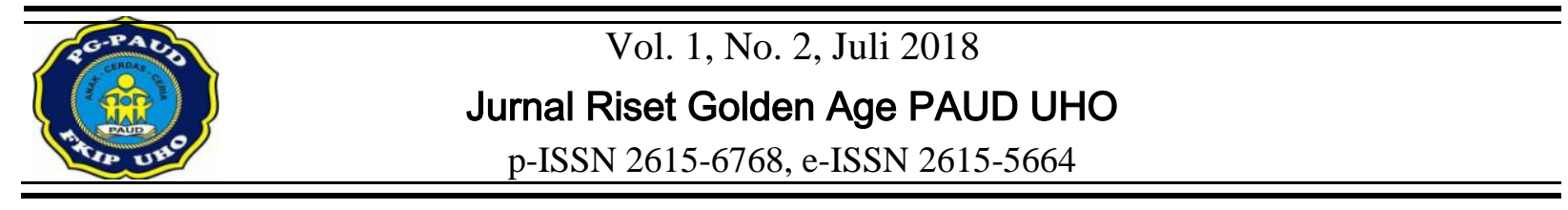

\title{
MENINGKATKAN KEMAMPUAN MOTORIK KASAR ANAK MELALUI GERAK DAN LAGU DI TK DHARMA WANITA KECAMATAN MORAMO
}

\author{
Lili Yulianti Sigari ${ }^{1)}$, Salwiah ${ }^{2)}$ \\ ${ }^{1}$ Alumni Jurusan PG-PAUD, Universitas Halu Oleo. Jln. H.E.A Mokodompit, Kendari 93232, \\ Indonesia. \\ ${ }^{2}$ Dosen Jurusan PG-PAUD, Universitas Halu Oleo. Jln. H.E.A Mokodompit, Kendari 93232, \\ Indonesia.
}

\begin{abstract}
Abstrak
Penelitian ini bertujuan untuk meningkatkan kemampuan motorik kasar anak melalui gerak dan lagu di TK Dharma Wanita Kelurahan Lapuko Kecamatan Moramo. Penelitian ini merupakan penelitian tindakan kelas (PTK). Penelitian ini dilaksanakan dalam dua siklus. Tahapan dalam penelitian ini mengikuti prosedur penelitian tindakan kelas yaitu perencanaan, pelaksanaan tindakan, observasi/pengamatan, dan refleksi. Subjek dalam penelitian ini adalah guru dan anak didik pada Kelompok B TK Dharma Wanita Kecamatan Moramo yang berjumlah 20 orang. Hasil penelitian tentang kemampuan motorik kasar anak melalui gerak dan lagu menunjukkan bahwa terdapat peningkatan, hal ini dapat ditunjukkan pada hasil sebelum tindakan dan sesudah tindakan. Sebelum tindakan diperoleh persentase sebesar 30\% dan mengalami peningkatan pada siklus I yaitu sebesar 70\%. Pada siklus II diperoleh persentase sebesar 90\%. Dengan demikian dapat disimpulkan bahwa kemampuan motorik kasar anak dapat ditingkatkan melalui kegiatan gerak dan lagu di TK Dharma Wanita Kelurahan Lapuko Kecamatan Moramo tahun pelajaran 2015/2016.
\end{abstract}

Kata kunci: Motorik Kasar, Gerak, Lagu.

\section{IMPROVING MOTOR ROUGH ABILITY OF CHILDREN THROUGH MOVEMENT AND SONGS AT TK DHARMA WANITA IN MORAMO REGENCY}

\begin{abstract}
The purpose of this research was to increased motor rough ability of children through movement and songs at TK Dharma Wanita in Moramo Regency. The types of the research was classroom action research (CAR), that's conducted by two cycles. The types of the research follows by classroom action research procedure consist of planing, action, observation/evaluation, reflection. The subject in this study were all the teachers and students at TK Dharma Wanita in Moramo Regency that's 20 people. The result of research that's children motor rough ability through movement and songs show that there is upgrading, its means could be showed before and after action. Before action getting percentage of $30 \%$ and more increased at the first cycle that's $70 \%$. and then the action of second cycles getting percentage of $90 \%$. The research could be conclude that the children motor rough ability could be upgrading through movement and songs at TK Dharma Wanita in Moramo Regency in school years 2015/2016.
\end{abstract}

Keywords: Motor Rough, Movement, Songs.

\section{PENDAHULUAN}

Golden age adalah masa-masa keemasan seorang anak, yaitu masa ketika anak mempunyai banyak potensi yang sangat baik untuk dikembangkan. Pada tahap inilah, waktu yang sangat tepat untuk menanamkan nilai-nilai kebaikan karakter yang nantinya diharapkan akan dapat membentuk kepribadiannya.

Pembelajaran pada anak usia dini lebih menekankan pada pembiasaan pada anak dan aspek-aspek perkembangan pada anak itu sendiri. Anak usia dini dipandang memiliki sebuah kreatifitas yang berbeda dibandingkan dengan usia-usia yang ada setelah usia tersebut. 
Anak adalah generasi penerus bangsa yang kelak membangun bangsa Indonesia menjadi bangsa yang maju, maka pendidikan anak usia dini sangat penting bagi keluarga untuk menciptakan generasi sumber daya manusia yang lebih baik.

Pendidikan yang diberikan kepada anak sejak dini tidak seperti pendidikan yang sangat formal seperti yang orang dewasa lakukan, harus berangkat ke sekolah dengan seragam, belajar secara serius, dan menaati aturan. Pembelajaran pada anak usia dini lebih menekankan pada pembiasaan pada anak dan aspek-aspek perkembangan pada anak itu sendiri.Anak usia dini dipandang memiliki sebuah kreatifitas yang berbeda dibandingkan dengan usia-usia yang ada setelah usia tersebut. Anak adalah generasi penerus bangsa yang kelak membangun bangsa Indonesia menjadi bangsa yang maju, maka pendidikan anak usia dini sangat penting bagi keluarga untuk menciptakan generasi sumber daya manusia yang lebih baik.

Pada anak usia TK, perkembangan kemampuan fisik anak mengalami perkembangan secara pesat dan cepat, proses kemampuan fisik kelenturan tubuh anak berkembang secara pesat dan cepat pada usia TK. Tumbuh kembang kemampuan fisik kelenturan tubuh anak tentunya berhubungan dengan proses perkembangan gerak anak.

Setiap anak, menggunakan sebagian besar tubuhnya dalam bergerak seperti berlari, berjalan, dan melempar, berjingkat. Anak juga melakukan gerakan tubuh yang bersifat keterampilan terbatas, seperti menggunting, menempel, dan mendorong. Samsudin (2008: 19) menyatakan perkembangan gerak berupa peningkatan kualitas penguasaan pola gerak yang telah bisa dilakukan pada masa bayi., serta peningkatan variasi berbagai macam pola-pola gerakan dasar. Kemampuan berjalan dan memegang akan semakin baik dan bisa dilakukan dengan berbagai macam variasi gerakan, beberapa macam gerak dasar dan variasinya yang makin dikuasai atau bisa dilakukan, yaitu berjalan, mendaki, meloncat, berjingkat, melempar dan menangkap.

Kemampuan gerak seorang anak pada dasarnya berkembang sejalan dengan kematangan syaraf dan otot anak, sehingga setiap gerakan sederhana apapun dapat menghasilkan interaksi yang kompleks dari berbagai bagian dan sistem dalam tubuh yang dikontrol oleh otak proses tumbuh kembang kemampuan motorik anak berhubungan dengan proses tumbuh kembang kemampuan gerak anak. Perkembangan kemampuan motorik anak akan dapat terlihat secara jelas melalui gerakan dan permainan yang dapat mereka lakukan. Peningkatan keterampilan fisik anak juga berhubungan erat dengan kegiatan bermain yang merupakan aktivitas utama anak usia dini.

Perkembangan motorik merupakan salah satu faktor yang sangat penting dalam perkembangan individu secara keseluruhan. Beberapa pengaruh perkembangan motorik terhadap konstelasi perkembangan individu dipaparkan oleh Hurlock (1996) sebagai berikut:

1. Melalui keterampilan motorik, anak dapat menghibur dirinya dan memperoleh perasaan senang. Seperti anak merasa senang dengan memiliki keterampilan memainkan boneka, melempar, dan menangkap bola atau memainkan alat-alat mainan.

2. Melalui keterampilan motorik, anak dapat beranjak dari kondisi tidak berdaya pada bulan-bulan pertama dalam kehidupannya, ke kondisi ysng independen. Anak dapat bergerak dari satu tempat ke tempat lainnya dan dapat berbuat sendiri untuk dirinya. Kondisi ini akan menunjang perkembangan rasa percaya diri.

3. Melalui perkembangan motorik, anak dapat menyesuaikan dirinya dengan lingkungan sekolah. Pada usia prasekolah atau usia kelas-kelas awal sekolah dasar, anak sudah dapat dilatih menulis, menggambar, melukis, dan baris-berbaris.

4. Melalui perkembangan motorik yang normal memungkinkan anak dapat bermain atau bergaul dengan teman sebayanya, sedangkan yang tidak normal akan menghambat anak untuk dapat bergaul dengan teman sebayanya bahkan dia akan terkucilkan atau menjadi anak yang fringer (terpinggirkan).

5. Perkembangan keterampilan motorik sangat penting bagi perkembangan self-concep atau kepribadian anak.

Pengembangan keterampilan motorik kasar meliputi kegiatan seluruh tubuh atau bagian tubuh. Perkembangan keterampilan motorik menggunakan bermacam koordinasi kelompok otot-otot tertentu sehingga dapat belajar untuk merangkak, melempar atau meloncat. Koordinasi keseimbangan, ketangkasan, kelenturan, kekuatan, kecepatan dan ketahanan merupakan kegiatan motorik kasar. Sujiono (2007:1.13), berpendapat bahwa gerakan motorik kasar terbentuk saat anak mulai memiliki koordinasi dan keseimbangan hampir 
seperti orang dewasa, gerakan motorik kasar memiliki kemampuan yang membutuhkan sebagian besar bagian tubuh anak dan memerlukan tenaga sehingga anak dapat meloncat, dan berlari.

Berdasarkan observasi awal yang dilakukan, di Kelompok B TK Dharma Wanita Kelurahan Lapuko Kecamatan Moramo bahwa sebagian anak terlihat belum mampu melakukan gerakan-gerakan dasar sesuai irama musik sesuai ketukan. Salah satu alternatif mengatasi masalah tersebut yaitu melalui gerak dan lagu. Melalui kegiatan ini anak dapat mengembangkan kemampuan motorik kasar. Salah satu aspek yang terdapat dalam kegiatan ini adalah gerak dasar. Selain dapat melatih gerak dasar, melalui kegiatan gerak dan lagu anak juga dapat menyalurkan kebutuhan untuk bergerak secara ekspresif dan kreatif. Melalui gerak dan lagu anak dapat mengekspresikan keinginan, perasaan, dan ide yang ada dalam pikirannya. Kegiatan gerak dan lagu sebagai bahan penting dari keseluruhan pengalaman gerak yang memberikan sumbangan berarti bagi pertumbuhan dan perkembangan motorik kasar anak.

Perkembangannya gerak dasar terjadi sejalan dengan perkembangan fisik. Perkembangan kemampuan gerak yang terjadi mulai bisa dilakukan ada dengan berbagai macam pola-pola gerak dasar, yang didukung oleh berkembangnya koordinasi mata, tangan dan kaki. Anak memiliki minat yang besar untuk selalu melakukan aktivitas gerak fisik, sehingga tampak selalu aktif bergerak. Kamtini (2005: 67) menyatakan bahwa gerak dasar adalah merupakan dasar untuk macam-macam keterampilan dan merupakan gerak alami yang dapat dilihat, didengar, dan dirasakan secara sadar dan akan menunjukkan keterampilan bertahap.

Gerak dan lagu sangat berperan penting khususnya dalam perkembangan motorik kasar anak, karena diketahui karakteristik anak usia dini merupakan individu yang aktif dan terus bergerak.Anak usia dini membutuhkan hal-hal yang mampu mengembangkan motorik kasar anak. Melalui pembelajaran seni tari anak dapat mengembangkan perkembangan motorik kasar anak.Seperti yang dikemukakan oleh Susane K.Langer dalam Kamtini (2005: 67) yang mengungkapkan bahwa gerak-gerak ekspresif adalah gerak-gerak yang indah, yang dapat menggetarkan perasaan manusia.
Humardani (1991) menyatakan bahwa gerak tari adalah suatu ekspresi yang paling mendasar dan paling tua yang diungkapkan melalui gerak, yang sudah diolah sedemikian rupa sehingga mampu memberikan grafikan emosi penciptanya, baik perasaan senang, sedih, dendam, dan sebagainya.

Karakteristik gerak tari anak dapat dilihat dari perkembangannya, menurut Kamtini (2005 : 80) perkembangan anak umumnya dapat melakukan kegiatan bergerak yaitu: (a) menirukan. Anak-anak dalam bermain senang menirukan sesuatu yang dilihatnya; (b) manipulasi. Dalam hal ini anak-anak secara spontan menampilkan gerak-gerak dari obyek yang diamatinya. Tetapi dari pengamatan obyek tersebut anak menampilkan gerak yang disukainya.

Gerak dan Lagu adalah sebuah materi pembelajaran yang diterapkan oleh guru pada saat mengajar peserta didiknya dengan cara bernyanyi sambil bergerak. Dalam hal ini gerak dan lagu memilik pengertian masing-masing yaitu gerak adalah aktifitas memainkan anggota tubuh sehingga posisi maupun bentuknya berubah. Sedangkan lagu yaitu menyanyikan syair/kalimat sehingga menjadi enak didengar. Perpaduan keduanya dapat kita berikan pengertian yaitu menyanyikan syair sambil memainkan anggota tubuh yang satu dengan yang lainnya secara bersamaan.

\section{METODE}

Jenis penelitian yang digunakan adalah Penelitian Tindakan Kelas (PTK) atau Classroom Action Research (CAR). Dari upaya yang dilakukan oleh guru bertujuan untuk memperbaiki dan meningkatkan kemampuan motorik kasar anak melalui Gerak dan Lagu.

Arikunto (2006 : 2-3) menyatakan bahwa Penelitian Tindakan Kelas (PTK) merupakan suatu pencermatan terhadap kegiatan pembelajaran berupa sebuah tindakan, yang sengaja dimunculkan yang terjadi dalam sebuah kelas secara bersamaan. Hopkins dalam Wiraatmaja (2007 : 11) mengartikan Penelitian Tindakan Kelas (PTK) untuk membantu seseorang dalam mengatasi secara praktis persoalan yang dihadapi dalam situasi darurat dan membantu pencampaian tujuan.

Penelitian ini akan dilaksanakan pada tanggal 21 Maret sampai 9 April 2016 di Kelompok B TK Dharma Wanita Kelurahan Lapuko Kecamaatan Moramo Kabupaten Konawe Selatan. 
Subjek dalam penelitian ini adalah guru dan anak didik pada Kelompok B TK Dharma Wanita Kelurahan Lapuko, berjumlah 28 orang terdiri atas 11 orang anak perempuen dan 9 orang anak laki-laki dengan rentang usia 5-6 tahun.

Prosedur penelitian tindakan kelas ini dibagi dalam dua siklus dimana setiap setiap siklus dari empat kali pertemuan yaitu sesuai dengan rencana seperti apa yang telah didesain dan faktor yang diselidiki. Desain yang telah digunakan dalam penelitian ini adalah desain yang dikemukakan oleh Iskandar (2012: 48) menjelaskan bahwa prosedur Penelitian Tindakan Kelas (PTK) dimulai dengan siklus pertama yang terdiri dari empat kegiatan, yaitu :

a) Perencanaan (planing)

b) Pelaksanaan (action)

c) Observasi/pengamatan (observing)

d) Refleksi (reflecting)

Data penelitian ini diperoleh melalui hasil wawancara, observasi dan dokumentasi. Dalam penelitian ini, yang diwawancarai adalah guru Kelompok B TK Dharma Wanita Kelurahan Lapuko Kecamatan Moramo. Observasi dilakukan oleh guru Kelompok B sebagai observer dengan menggunakan lembar observasi. Sedangkan dokumentasi yang dimaksudkan untuk memperoleh data dengan melihat kondisi riil di lapangan dalam hal ini di kelas saat pelaksanaan pembelajaran melalui kegiatan gerak dan lagu. Dokumentasi ini berupa foto guru/peneliti dan aktivitas anak yang dimaksudkan sebagai bahan pendukung dalam penelitian ini.

Pengolahan data dalam penelitian ini dianalisis berdasarkan hasil penilaian tentang kemampuan motorik kasar anak melalui gerak dan lagu. Dalam menganalisis data dan memberi penilaian pada setiap indikator kinerja, peneliti mengacu pada pedoman pemberian penilaian dalam satuan pendidikan di taman kanak-kanak, yaitu dengan penilaian secara kualitatif atau dengan memberikan nilai dalam bentuk simbol bintang, sebagai berikut: $*=$ belum berkembang $(\mathrm{BB}),{ }^{* *}=$ mulai berkembag $(\mathrm{MB}), * * *=$ berkembang sesuai harapan (BSH), **** = berkembang dengan baik (BSB) (Depdiknas, 2004: 26).

\section{HASIL DAN PEMBAHASAN}

Penelitian dilakukan dalam 2 siklus yaitu siklus I 4 kali pertemuan dan siklus II 4 kali pertemuan. Berdasarkan hasil penelitian siklus I pertemuan 1 sampai 4 menunjukkan bahwa rata- rata perolehan nilai anak didik berada pada taraf nilai bintang $(* * *)$ atau Berkembang Sesuai Harapan (BSH). Data hasil observasi/pengamatan seperti yang ditampilkan pada Table 1, maka dilakukan analisis keberhasilan tindakan secara klasikal dan diperoleh hasil seperti berikut ini.

Tabel 1. Perhitungan Nilai Klasikal pada Tindakan Siklus I.

\begin{tabular}{lcc}
\hline \multicolumn{1}{c}{ Kategori } & Jumlah & Persentase \\
\hline $\begin{array}{l}\text { Banyak anak } \\
\text { memperoleh BSB }\end{array}$ & 3 & $15 \%$ \\
\hline $\begin{array}{l}\text { Banyak anak } \\
\text { memperoleh BSH }\end{array}$ & 11 & $55 \%$ \\
\hline $\begin{array}{l}\text { Banyak anak } \\
\text { memperoleh MB }\end{array}$ & 4 & $20 \%$ \\
\hline $\begin{array}{l}\text { Banyak anak } \\
\text { didik yang } \\
\text { memperoleh BB }\end{array}$ & 2 & $10 \%$ \\
\hline $\begin{array}{l}\text { Presentase } \\
\text { keberhasilan } \\
\text { (BSB+ BSH) }\end{array}$ & 14 & $70 \%$ \\
\hline \multicolumn{1}{c}{ Jumlah } & 20 & 100 \\
\hline
\end{tabular}

Berdasarkan hasil yang diperoleh pada Tabel 1 terlihat bahwa secara klasikal meningkatkan kemampuan motorik kasar anak melalui kegiatan gerak dan lagu pada Kelompok B TK Dharma Wanita Kecamatan Moramo pada tahap penilaian siklus I, rata-rata anak didik memperoleh nilai bintang (***) atau Berkembang Sesuai Harapan (BSH) dengan persentase 55\% yaitu 11 orang anak didik dari 20 orang anak secara keseluruhan. Nilai bintang $(* * * *)$ atau berkembang Sangat Baik (BSB) dengan persentase $25 \%$ yaitu diperoleh 3 orang anak didik, untuk nilai bintang (**) atau mulai berkembang (MB) dengan persentase $20 \%$ yaitu diperoleh 4 orang anak didik, sedangkan untuk nilai bintang (*) atau Belum Berkembang (BB) dengan persentase $10 \%$ yaitu diperoleh 2 orang anak didik.

Berdasarkan hasil evaluasi tersebut, sebagian besar anak sudah dapat melaksanakan kegiatan dengan baik namun belum mencapai indikator kinerja yaitu $75 \%$ jika anak didik memperoleh nilai Berkembang Sesuai Harapan (BSH) dan berkembang Sangat Baik (BSB).

Berdasarkan hasil penelitian siklus II (pertemuan 1 sampai 4) menunjukkan bahwa rata-rata perolehan nilai anak didik berada pada taraf nilai bintang $(* * *)$ atau Berkembang Sesuai Harapan $(\mathrm{BSH})$ dan nilai bintang $(* * * *)$ 
atau Berkembang Sangat Baik (BSB). Data hasil observasi/pengamatan seperti yang ditampilkan pada Table 2, maka dilakukan analisis keberhasilan tindakan secara klasikal dan diperoleh hasil seperti berikut:

Tabel 2. Perhitungan Nilai Klasikal pada Tindakan Siklus II.

\begin{tabular}{|l|c|c|}
\hline \multicolumn{1}{|c|}{ Kategori } & Jumlah & Persentase \\
\hline $\begin{array}{l}\text { Banyak anak } \\
\text { memperoleh BSB }\end{array}$ & 9 & $45 \%$ \\
\hline $\begin{array}{l}\text { Banyak anak } \\
\text { memperoleh BSH }\end{array}$ & 9 & $45 \%$ \\
\hline $\begin{array}{l}\text { Banyak anak } \\
\text { memperoleh MB }\end{array}$ & 2 & $10 \%$ \\
\hline $\begin{array}{l}\text { Banyak anak } \\
\text { memperoleh BB }\end{array}$ & 0 & $0 \%$ \\
\hline $\begin{array}{l}\text { Presentase } \\
\text { keberhasilan } \\
\text { (BSB+ BSH) }\end{array}$ & 18 & $90 \%$ \\
\hline \multicolumn{1}{|c|}{ Jumlah } & 20 & 100 \\
\hline
\end{tabular}

Berdasarkan data hasil perolehan nilai anak didik yang ditampilkan pada Tabel 2 di atas, maka dapat disimpulkan bahwa secara klasikal perolehan nilai anak didik dalam kegiatan meningkatkan kemampuan motorik kasar anak melalui gerak dan lagu pada Kelompok B TK Dharma Wanita Kecamatan Moramo mengalami peningkatan, karena tingkat keberhasilan anak didik yaitu sebesar 90\% (lampiran 9). Anak didik yang memperoleh nilai bintang (****) atau Berkembang Sangat Baik (BSB) yaitu sebanyak 9 orang anak didik dengan persentase $45 \%$, nilai bintang (***) atau Berkembang Sesuai Harapan (BSH) yaitu sebanyak 9 orang anak didik dengan persentase $45 \%$, untuk yang memperoleh nilai bintang (**) atau Mulai Berkembang (MB) yaitu sebanyak 2 orang anak didik dengan persentase $10 \%$.

Walaupun masih terdapat anak didik yang memperoleh nilai bintang (**) atau Mulai Berkembang (MB) tetapi dapat dikatakan bahwa sebagian besar anak didik dipandang telah mampu menyelesaikan tugas-tugas yang telah ditetapkan sesuai dengan indikator penilaian dalam penelitian ini khususnya dalam pelaksanaan tindakan siklus II. Selain itu dengan perolehan nilai sebesar $90 \%$ tersebut telah dicapai oleh 18 orang anak didik, sehingga secara umum dapat dikatakan bahwa program kegiatan atau rangkaian pelaksanaan pembelajaran dalam meningkatkan kemampuan motorik kasar anak melalui gerak dan lagu pada
Kelompok B TK Dharma Wanita Kecamatan Moramo dipandang telah terselesaikan dan mencapai indikator kinerja yaitu $75 \%$.

Berdasarkan data yang diperoleh pada kedua tabel tersebut, dapat diketahui perbandingan jumlah anak yang memiliki kemampuan motorik kasar dengan kriteria Berkembang Sangat Baik (BSB) dan Berkembang Sesuai Harapan (BSH), sebelum tindakan/observasi awal sebanyak 6 orang anak didik, setelah pelaksanaan siklus I mengalami peningkatan menjadi 14 orang anak didik dan siklus II meningkat lagi menjadi 18 orang anak didik.

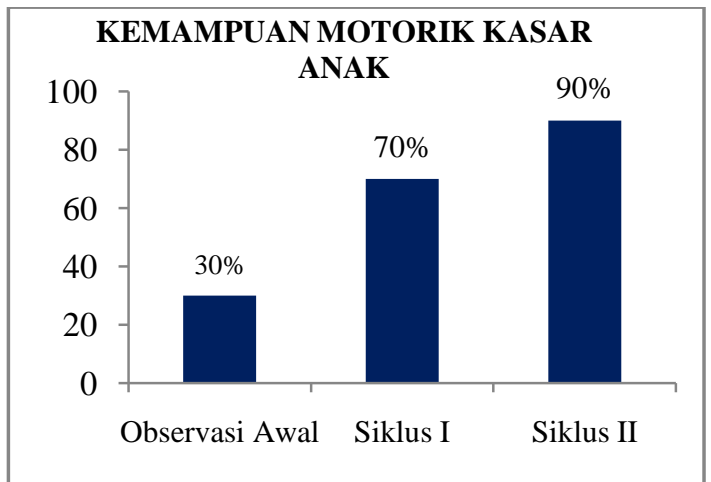

\section{Gambar 1. Rekapitulasi Kemampuan Motorik} Kasar Anak

Selama kegiatan penelitian berlangsung, data hasil temuan yang diperoleh sebagaimana dideskripsikan pada halaman sebelumnya, dapat diasumsikan bahwa kegiatan pembelajaran dalam meningkatkan kemampuan motorik kasar anak melalui gerak dan lagu yang dirancang, disusun dan dilaksanakan secara baik dan optimal oleh peneliti yang berkolaborasi dengan guru Kelompok B pada setiap pertemuan siklus I dan siklus II sangat memberikan manfaat pada anak didik dengan pengalaman langsung dan konkret, serta kemampuan motorik anak menunjukkan peningkatan. Jika dilihat dari pemahaman anak didik mulai dari pelaksanaan siklus I sebesar $70 \%$ jika dibandingkan pada tahapan observasi awal/prasiklus penelitian yang hanya mencapai $30 \%$ dan pada tindakan siklus II mencapai persentase sebesar 90\%, menunjukkan hasil yang lebih baik dari sebelumnya, karena indikator kinerja yang ditetapkan telah tercapai yaitu minimal $75 \%$ maka penelitian ini dapat dihentikan. 


\section{KESIMPULAN DAN SARAN}

Berdasarkan hasil penelitian dan pembahasan maka kemampuan motorik kasar anak didik dapat meningkat melalui kegiatan gerak dan lagu di Kelompok B TK Dharma Wanita Kelurahan Lapuko Kecamatan Moramo. Namun, masih ada 2 orang anak didik yang belum berhasil, dalam hal ini anak diberikan bimbingan pembelajaran.

Setelah melaksanakan tindakan penelitian yaitu meningkatkan kemampuan motorik kasar anak melalui gerak dan lagu dan melihat proses pembelajaran serta hasil belajar yang diperoleh, maka peneliti menyarankan hal-hal sebagai berikut: (1) diharapkan kepada guru, dalam pelaksanaan pembelajaran hendaknya guru dituntut untuk selalu kreatif dan inovatif dalam memeilih media sebagai sarana dan prasarana untuk melaksanakan proses pembelajaran dan kegiatan-kegiatan yang dapat meningkatkan potensi anak didik, (2) bagi sekolah memberikan dan menyediakan fasilitas yang mendukung dan kegiatan yang berhubungan dengan gerak dan lagu untuk meningkatkan kemampuan motorik anak.

\section{DAFTAR PUSTAKA}

Arikunto, Suharsimi, et. al. 2006. Penelitian Tindakan Kelas. Jakarta: Bumi Aksara.

Humardani, SD. 1991. Sekedar Tentang Tari dalam Gendhon Humar dani: Pemikiran dan Kritiknya, Rustopo (ed.).Surakarta: STSI Press Surakarta

Hurlock, Elizabeth., 1996. Psikologi Perkembangan: Suatu Kehidupan Sepanjang Rentang Kehidupan. Edisi kelima. Jakarta: Penerbit Erlangga.

Kamtini. 2005. Bermain Melalui Gerak dan Lagu. Jakarta: Direktorat Pembinaan Pendidikan Tenaga Kependidikan dan Ketenagaan Perguruan Tinggi

Samsudin. 2008. Pembelajaran Motorik di Taman Kanak-kanak. Jakarta: Litera Prenada Media Group

Sujiono, Bambang. dkk. 2008. Metode Pengembangan Fisik. Jakarta: Universitas Terbuka.
Wiriaatmadja, R. 2006. Metode Penelitian Tindakan Kelas Untuk Meningkatkan Kerja Guru dan Dosen. Bandung: Remaja Rosdakarya 